\title{
Patterns and inferred processes associated with sea turtle strandings in Paraíba State, Northeast Brazil
}

\author{
Poli, C. . ${ }^{a, b *}$, Lopez, LCS. ${ }^{a}$, Mesquita, DO. ${ }^{a}$, Saska, C. ${ }^{a, b}$ and Mascarenhas, ${ }^{a} .^{a, b}$ \\ aDepartamento de Sistemática e Ecologia, Centro de Ciências Exatas e da Natureza, Universidade Federal da Paraíba - UFPB, \\ Cidade Universitária, Castelo Branco, CEP 58059-900, João Pessoa, PB, Brazil \\ bProjeto Tartarugas Urbanas, Associação Guajiru: Ciência - Educação - Meio Ambiente, \\ Av. Litorânea, Intermares, CEP 58310-000, Cabedelo, PB, Brazil. \\ *e-mail: camilapoli.cp@gmail.com
}

Received July 16, 2012 - Accepted February 14, 2013 - Distributed May 31, 2014

(With 1 figure)

\begin{abstract}
This study analysed sea turtle strandings on the coast of Paraíba State, Northeastern Brazil, from August 2009 to July 2010. A total of 124 strandings were recorded in this period: green turtle Chelonia mydas $(\mathrm{n}=106)$, hawksbill Eretmochelys imbricata $(\mathrm{n}=15)$, olive ridley Lepidochelys olivacea $(\mathrm{n}=2)$ and loggerhead Caretta caretta $(\mathrm{n}=1)$. Of all turtles for which the Curved Carapace Length $(C C L)$ was measured $(n=122)$, only 12 individuals $(9.7 \%)$ were adults. Twenty individuals had synthetic anthropogenic debris in the gastrointestinal tract. Other traces of human interactions were observed in 43 individuals, such as injuries caused by entanglement in fishing lines or nets, collisions with vessels, direct contact with oil spills and lesions caused by sharp or spiked objects. Moreover, in $28.5 \%$ of the stranded turtles, the presence of external tumors was noticed, suggestive of fibropapillomatosis and in $9.7 \%$, shark bite marks were observed. Of the 107 individuals that were sexed, 76 were females and 31 were males. Most turtles (72.6\%) became stranded during the spring/summer (between October and March). We found evidence of human interactions (injuries) in half of the strandings, but in most cases it was not possible to determine if such interactions were the cause of death. A logistic regression found a significant relationship between CCL, ingestion of debris and lesions caused by sharks or spiked objects. Systematic data collection from stranded sea turtles can provide useful biological information, such as seasonal and spatial patterns in their occurrence and mortality, age structure, sex ratio and diet, as well as possible mortality causes.
\end{abstract}

Keywords: threatened species, human impact, beach strandings, green sea turtle.

\section{Padrões e inferências associadas com encalhes de tartarugas marinhas no Estado da Paraíba, Nordeste do Brasil}

\section{Resumo}

Este estudo analisou encalhes de tartarugas marinhas na costa do Estado da Paraíba, Nordeste do Brasil, de agosto de 2009 a julho de 2010. Neste período, 124 encalhes foram registrados: tartaruga-verde Chelonia mydas $(\mathrm{n}=106)$, tartaruga-de-pente Eretmochelys imbricata $(\mathrm{n}=15)$, tartaruga-oliva Lepidochelys olivacea $(\mathrm{n}=2)$ e cabeçuda Caretta caretta $(\mathrm{n}=1)$. Dentre todas as tartarugas que tiveram o Comprimento Curvilíneo da Carapaça (CCC) medido $(\mathrm{n}=122)$, apenas 12 indivíduos $(9,7 \%)$ foram considerados adultos. Vinte indivíduos tinham detritos antropogênicos sintéticos no trato gastrointestinal. Em 43 indivíduos, outros vestígios de interações humanas foram observados, tais como lesões causadas por emaranhamento em linhas ou redes de pesca, colisões com embarcações, contato direto com derramamentos de óleo e lesões causadas por objetos perfurocortantes. Além disso, em 28,5\% das tartarugas encalhadas, foi observada a presença de tumores externos sugestivos de fibropapilomatose e em $9,7 \%$, foram observadas marcas de mordidas de tubarão. Dos 107 indivíduos sexados, 76 eram fêmeas e 31 eram machos. A maioria das tartarugas $(72,6 \%)$ encalhou durante a primavera/verão (entre outubro e março). Foram encontrados sinais de interações humanas (lesões) em metade dos encalhes, mas na maioria dos casos, não foi possível determinar se tais interações foram a causa da morte. A regressão logística encontrou uma relação significativa entre CCC e ingestão de detritos, lesões causadas por objetos perfuro-cortantes e ataques de tubarões. A coleta sistemática de dados de tartarugas marinhas encalhadas pode fornecer informações biológicas úteis, tais como padrões sazonais e espaciais na sua ocorrência e mortalidade, estrutura etária, razão sexual, dieta, bem como possíveis causas de mortalidade.

Palavras-chave: espécies ameaçadas, impacto humano, encalhes de praia, tartaruga verde. 


\section{Introduction}

Sea turtles are long-distance migratory animals and occupy niches in different marine environments and geographical regions throughout their different life cycle stages, usually ranging from pelagic environments, as hatchlings, to several coastal areas in their juvenile and adult stages (Bolten, 2003). Due to migratory habits, sea turtles are susceptible to threats in both offshore and coastal environments (Bolten, 2003). Five sea turtle species use the Brazilian coast for reproduction and feeding: loggerhead (Caretta caretta Linnaeus, 1758), green (Chelonia mydas Linnaeus, 1758), leatherback (Dermochelys coriacea Vandelli, 1761), olive ridley (Lepidochelys olivacea Eschscholtz, 1829) and hawksbill (Eretmochelys imbricata Linnaeus, 1766) (Marcovaldi and Dei Marcovaldi, 1999). All species are listed as threatened by extinction globally (IUCN, 2011) and nationally (Martins and Molina, 2008).

Sea turtles face a wide variety of stressors, mainly anthropogenic (Lutcavage et al., 1997). In Brazil, a major cause of sea turtle mortality is linked to incidental capture in fishing artifacts (Mascarenhas et al., 2005; Marcovaldi et al., 2006; Bugoni et al., 2008). Marine pollution is another serious threat that causes habitat degradation and turtle death through debris ingestion or entanglement (Bjorndal et al., 1994; Ivar do Sul and Costa, 2007). Along most of the Brazilian coast, ingestion of marine debris by sea turtles has frequently been reported (Bugoni et al., 2001; Mascarenhas et al., 2004; Tourinho et al., 2010; Guebert-Bartholo et al., 2011). Moreover, although prohibited in most of the world, all sea turtle species have been used for decades as a protein source, entailing the consumption of their meat or eggs, or as raw material in the manufacture of ornaments and artifacts (Marcovaldi and Dei Marcovaldi, 1999; Campbell, 2003).

In addition to human threats, sea turtles suffer the impacts of many types of disease, among which fibropapillomatosis (FP) is the most studied (Herbst, 1994). FP is a debilitating disease and can be lethal, or may impair the animal's ability to feed or swim (George, 1997).

Part of the dead or debilitated animals end up stranded on beaches, and this performs a fundamental role in ecological studies and species conservation (Epperly et al., 1996). Systematic data collection from stranded sea turtles can provide useful biological information, such as seasonal and spatial patterns in their occurrence and mortality, age structure, sex ratio, diet, interannual variations associated with climatic or anthropogenic events, as well as possible causes of mortality (Bjorndal, 1999). In Paraíba State, Northeastern Brazil, strandings of green, hawksbill, olive ridley and loggerhead sea turtles have been recorded (Mascarenhas et al., 2005; Mascarenhas and Iverson, 2008).

Given the current vulnerability of all sea turtle species, the systematic study of strandings, with an emphasis on research into their causes, is becoming increasingly urgent. This study aimed to examine sea turtle strandings on the coast of Paraíba State from August 2009 to July 2010, testing the following hypotheses: (1) The occurrence of different species strandings is not homogeneous among species and seasons; (2) There is significant difference in the occurrence of strandings among life stages and sexes; (3) There is a relationship between Curved Carapace Length (CCL) and events associated with stranding.

\section{Material and Methods}

The study was conducted from August 2009 to July 2010 on the coast of Paraíba State, Northeastern Brazil, along $15 \mathrm{~km}$ of urban beaches in the municipalities of João Pessoa ( $\left(7^{\circ} 08^{\prime} \mathrm{S}\right.$ and $\left.34^{\circ} 48^{\prime} \mathrm{W}\right)$ and Cabedelo $\left(7^{\circ} 01^{\prime} \mathrm{S}\right.$ and $34^{\circ} 49^{\prime} \mathrm{W}$ ) (Figure 1). Daily monitoring was performed between Bessa ( $7^{\circ} 05^{\prime} \mathrm{S}$ and $\left.34^{\circ} 49^{\prime} \mathrm{W}\right)$ and Ponta de Campina ( $7^{\circ} 01^{\prime} \mathrm{S}$ and $\left.34^{\circ} 49^{\prime} \mathrm{W}\right)$. For the remaining area (Cabo Branco, Tambaú and Manaíra beaches), stranding observations were reported to the researchers through partnerships with environmental agencies and the local community, via a telephone line, "SOS Turtles".

In the case of dead individuals, the external data were collected at the stranding location, such as the carcass decomposition stage, evidence of anthropogenic interaction, presence of tumors, presence of individual marks and evidence of interaction with other fauna. The carcass decomposition stage was divided into categories: a) without decomposition evidence; b) moderate decomposition; and c) advanced decomposition. CCL and the Curved Carapace Width (CCW) were measured using a flexible tape with $0.1 \mathrm{~cm}$ accuracy. Individuals were classified as juveniles or adults based on CCL measurements, considering the minimum values of nesting females in nearby beaches (see Baptistotte et al., 2003; Grossman et al., 2007; Marcovaldi and Chaloupka, 2007; Silva et al., 2007; Santos et al., 2010 for reference values).

After the collection of external data, carcasses were necropsied to collect additional data such as sex by gonad examination, observation of internal tumors and digestive tract analysis in search of anthropogenic material. Gastrointestinal tracts were removed from the esophagus to the final portion of the intestine, and each organ was analysed separately. Gastrointestinal content was washed using sieves and, when present, anthropogenic debris was

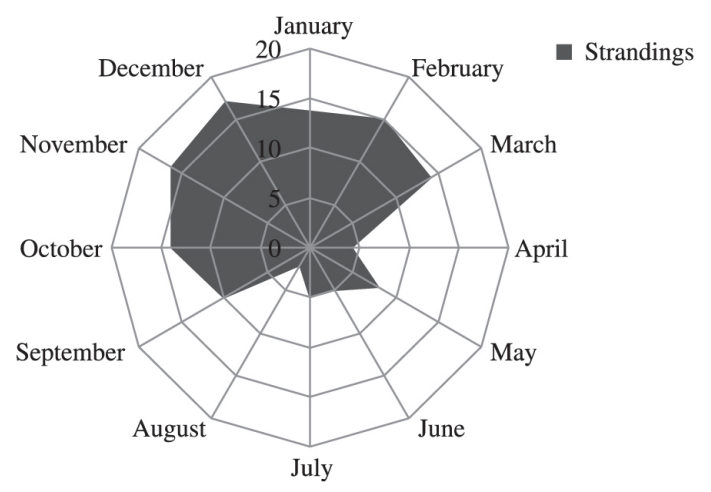

Figure 1. Strandings distribution in the different months between August 2009 and July 2010 on the Paraíba coast. 
separated from organic items. Animals stranded alive were moved to rehabilitation in the "Projeto Tartarugas Urbanas" after external data collection. Animals that died during rehabilitation underwent the same necropsy procedure.

Homogeneity in the occurrence of different stranded species was confirmed using a Kolmogorov-Smirnov test (Ayres et al., 2007). Other tests were performed only for species where the number of strandings was above 20 individuals. A Chi-square test was applied to verify homogeneity in the occurrence of juvenile and adult strandings (Ayres et al., 2007). We performed a Kolmogorov-Smirnov test (Ayres et al., 2007) to test whether the occurrence of anthropogenic interactions was homogeneous. We also performed a logistic regression (Fox, 2005) between the CCL and the possible causes of stranding in order to determine whether there was a relationship between the size of the turtle and the different interactions observed. A Chi-square test was applied to verify homogeneity in the occurrence of male and female strandings (Ayres et al., 2007). A Chi-square test was applied to confirm differences in the occurrence of strandings in the winter and summer, and a Rayleigh test was also performed in order to highlight the period of highest stranding occurrence (Ayres et al., 2007). For all statistical analyses, results were considered significant at an alpha 0.05 level (Zar, 1999).

\section{Results}

From August 2009 to July 2010, 124 sea turtle strandings were recorded in the study area. Fifteen turtles (12.1\%) were stranded alive but died during the rehabilitation period. Regarding the decomposition status of the carcass, $19(17.4 \%)$ were fresh, $29(26.6 \%)$ were moderately decomposed and $61(56.0 \%)$ were in an advanced state of decomposition. Parts of the carcasses were missing in 20 individuals (16.1\%). A total of 98 necropsies were performed. The occurrence of stranded species was not homogeneous (Kolmogorov-Smirnov maximum deviation $=0.604, \mathrm{p}<0.01): 106$ green turtles $(85.4 \%), 15$ hawksbill (12.1\%), two olive ridley (1.6\%) and one loggerhead (0.9\%).

Regarding age class, for all stranded turtles that were measured $(n=122)$, only twelve individuals $(9.7 \%)$ could be considered adults (Table 1). The CCL and CCW of two green turtles could not be measured due to the lack of a partial or whole carapace. There was a significant difference between the occurrence of juvenile and adult green turtles $\left(\chi_{\text {YATES }}^{2}=40.9, \mathrm{p}=0.0001\right)$, with nine adults observed
$(8.6 \%, n=9 / 104)$; for the other species, three hawksbills and the only loggerhead were considered adult (Table 1).

A total of 98 gastrointestinal tracts were analysed, of which 20 (20.4\%) contained synthetic anthropogenic debris: 13 green turtles $(65.0 \%), 5$ hawksbill $(25.0 \%)$ and 2 olive ridley (10.0\%). Moreover, 43 individuals (41.3\%) of the 104 whole carcasses showed other evidence of human interactions, such as injuries caused by entanglement in lines or nets $(33.6 \%)$, collisions with vessels (3.8\%), sharp or spiked objects $(3.8 \%)$ and direct contact with oil spills $(0.96 \%)$. The proportion of anthropogenic interactions was not homogeneous for green turtles (Kolmogorov-Smirnov maximum deviation $=0.383, \mathrm{p}<0.01$ ).

In addition to the evidence of human interactions, other carcasses showed signs that could be linked to causes of debilitation that had possibly resulted in the stranding. In $28.5 \%(n=30 / 105)$ of the stranded turtles, considering the carcasses that were intact, the presence of external tumors was noted, suggestive of FP, and even those that were incomplete showed the same type of tumors. All individuals that presented these tumors were green turtles, with CCLs ranging between 37.9 and $76.4 \mathrm{~cm}(=54 \mathrm{~cm})$. Shark bite marks were observed in $9.7 \%(n=124)$ of the carcasses. Of the 12 animals that showed evidence of interactions with sharks, only two had a CCL $<75 \mathrm{~cm}$, indicating that they were either large juveniles or adults.

A logistic regression, performed for green sea turtle data, showed a significant relationship between the CCL and ingestion of anthropogenic debris (estimate $=-0.048$, $\mathrm{p}=0.03$ ); between the CCL and injuries caused by sharp or spiked objects (estimate $=0.072, \mathrm{p}=0.01$ ); and between the CCL and interactions with sharks (estimate $=0.046, \mathrm{p}=$ 0.001 ). The regression revealed no significant relationship for the remaining observations of possible causes of stranding (entanglement in lines and nets, collisions with vessels, contact with oil and tumors suggestive of FP_ Table 2).

Regarding sex, in 17 carcasses (13.7\%) it was not possible to determine gender due to the advanced stage of decomposition. Of the 107 individuals sexed, 76 (71\%) were females and 31 (29\%) were males. Female green sea turtles predominated $\left(\chi_{\text {YATES }}^{2}=8.8, p=0.003\right)$ : of 91 individuals sexed, $66(72.5 \%)$ were females and 25 $(27.5 \%)$ were males. Regarding seasonality, strandings predominated in the spring/summer $(76.6 \%, \mathrm{n}=90$; $\left.\chi_{\text {YATES }}^{2}=12.3, p=0.0004\right)$. A Rayleigh test confirmed that the distribution of stranding occurrences was not uniform $(\mathrm{R}=38.9, \mathrm{p}<0.01)$, indicating a higher incidence of strandings between October and February (Figure 1).

Table 1. Curved Carapace Length (CCL) and Curved Carapace Width (CCW) (mean and standard deviation) of the turtle species collected in strandings on the Paraíba coast between August 2009 to July 2010. The maximum and minimum are in parentheses.

\begin{tabular}{ccc}
\hline Species & CCL $(\mathbf{c m})$ & CCW $(\mathbf{c m})$ \\
\hline C. mydas $(\mathrm{n}=104)$ & $56.6 \pm 21.5(24.0-123.5)$ & $52.2 \pm 20.3(22.2-111.7)$ \\
E. imbricata $(\mathrm{n}=15)$ & $48.8 \pm 21.6(30.9-91.2)$ & $43.3 \pm 19.9(26.0-84.7)$ \\
L. olivacea $(\mathrm{n}=2)$ & $61.6 \pm 2.3(60.0-63.3)$ & $66.0 \pm 2.2(64.4-67.6)$ \\
C. caretta $(\mathrm{n}=1)$ & 93.5 & 86 \\
\hline
\end{tabular}


Table 2. Results of logistic regression performed between CCC and the possible causes of Chelonia mydas strandings.

\begin{tabular}{lcccc}
\hline \multicolumn{1}{c}{ Possible cause of stranding } & Estimate & Stand. Error & $\mathbf{Z}$ value & $\operatorname{Pr}(>|\mathbf{z}|)$ \\
\hline Ingestion of marine debris & -0.048 & 0.023 & -2.076 & $0.03^{*}$ \\
Entanglement in nets and lines & 0.001 & 0.010 & 0.129 & 0.8 \\
Collisions with vessels & -0.017 & 0.033 & -0.514 & 0.6 \\
Injuries caused by sharp or spiked objects & 0.072 & 0.030 & 2.364 & $0.01^{*}$ \\
Contact with oil spills & -0.138 & 0.139 & -0.994 & 0.3 \\
Shark attack & 0.046 & 0.014 & 3.107 & $0.001^{*}$ \\
Tumors suggestive of FP & -0.007 & 0.010 & -0.745 & 0.4 \\
\hline
\end{tabular}

* Statistical significance.

\section{Discussion}

Our results corroborate the study of Mascarenhas et al. (2005) in the same area, showing that green turtles are the most frequently stranded species. The same results have been found along the Brazilian coast, such as in Rio de Janeiro (Reis et al., 2009), Rio Grande do Sul (Bugoni et al., 2001) and Paraná (Guebert-Bartholo et al., 2011). Green turtles are found in many feeding grounds on the Brazilian coast (Marcovaldi and Dei Marcovaldi, 1999; Grossman et al., 2007), including the coral reefs of the Paraíba coast (Mascarenhas et al., 2005), which may explain the predominance of this species in strandings.

Hawksbills occurred in significantly lower numbers compared to green sea turtles; despite the Paraíba beaches having been recognised as a nesting site for this species (Mascarenhas et al., 2003), only three individuals were considered sexually mature, and so these strandings were not associated with their presence during the period of reproductive activity in the area. It is probable that hawksbill, olive ridley and loggerhead specimens died and became stranded between the migration from their nesting area to different foraging grounds. Whiting et al. (2007), in a study of olive ridley turtles in Australia, suggest that after the nesting season all turtles travel between 180 and $1050 \mathrm{~km}$ to different foraging areas, using coastal and continental habitats, and are able to forage during migration before reaching their foraging grounds. Telemetry studies in Brazil indicate that hawksbills migrate between nesting areas in Bahia and foraging grounds in Ceará State (Marcovaldi et al., 2011), and that there is a migratory corridor along the entire coast of Northeastern Brazil for loggerheads (Santos et al., 2011). Telemetry studies for olive ridley turtles in Brazil highlight that there is a displacement from the Espírito Santo coast to Pará State (Castilhos et al., 2011). Beyond telemetry studies, analysis of strandings along the Brazilian coast indicates that turtles could be migrating to more southern feeding areas, such as in the study of Reis et al. (2010a), which suggests that feeding areas for olive ridley turtles are found on the Rio de Janeiro coast. Considering this large home range, and all the natural and anthropogenic risks to which these animals are exposed, it is very plausible that they were stranded during migration from their nesting area to different foraging grounds.
Relative to life stage, similar studies in Brazil and elsewhere have also reported a higher incidence of juvenile strandings, irrespective of species (Bugoni et al., 2001; Chaloupka et al., 2008; Reis et al., 2009). One explanation for the high incidence of juvenile strandings is based on their cycle life. Juveniles of the green, hawksbill, olive ridley and loggerhead turtles usually migrate from ocean areas to neritic environments, where they complete their development and where there is greater food availability (Bolten, 2003). However, coastal areas typically support greater human activity and a greater accumulation of debris (Aguirre and Lutz, 2004), which makes the sea turtles more susceptible in these environments. Regarding sex ratio, females predominated, as is the case in previous reports of the area (Mascarenhas et al., 2005). Grossman et al. (2007), in a study on green turtles in Atol das Rocas, also report a higher frequency of females. The greater number of females stranded is probably due to the fact that females are more common in natural populations, in spite of there being no studies that report females to be more susceptible to threats than males in the marine environment.

It is evident in the present study and has been reported elsewhere that human activity remains the main cause of sea turtle mortality worldwide. In the present study, fishing activities followed by marine pollution were found to be the main threats to turtles on the Paraíba coast. The predominance of entanglement with fishing apparatus as the main human interaction registered in the stranded turtles corroborates other studies where fishing activity appears to be one of the most important anthropogenic-related sources of sea turtle mortality in the world (Marcovaldi et al., 2006; Bugoni et al., 2008; Casale et al., 2010). In Paraíba State, fishing is mainly artisanal, comprising sailboats and small motorboats fishing in shallow waters near the coast and in estuaries, deploying gillnets, hook-and-lines and fishing by manual collection (IBAMA, 2008). In lobster fishing on the Paraíba coast, $73 \%$ of the fishermen carry out their activities on the reefs and $24 \%$ between the reefs and the beaches, using gillnets in $49 \%$ of cases (Oliveira et al., 2009). Is important to note that this type of fishing activity is very dangerous for sea turtles, as has been reported by Lima et al. (2010).

The present study showed that ingestion of marine debris, especially plastic, is an important threat to sea turtles, with the smaller green sea turtles having a higher 
probability of ingesting plastic debris compared to larger ones, confirming the results of previous studies (Balazs, 1985; Plotkin and Amos, 1990). Synthetic materials are currently recognised as an important pollutant in marine and coastal environments, and are reported in many studies as the main type of debris found in these habitats (Ivar do Sul and Costa, 2007; Ryan et al., 2009). The physical and chemical effects of ingesting marine debris on sea turtles are widely described in the literature (McCauley and Bjorndal, 1999; Bugoni et al., 2001; Tourinho et al., 2010). These effects can be sub-lethal or lethal (Mascarenhas et al., 2004; Tourinho et al., 2010), and therefore this interaction is regarded as an important cause of stranding. Sea turtles are prone to the ingestion of solid residues, which may occur intentionally, when these residues are confused with their natural foods or accidentally, when they are ingested with food (Mrosovsky et al., 2009). Green sea turtles are particularly prone to ingesting a large amount of marine debris, mainly plastic, since it usually adheres to their main food resource, the algae (Reis et al., 2010b).

In addition to the ingestion of anthropogenic debris, it was possible to observe extreme oil contamination in the entire body of a single individual, including the oral and nasal cavities. The individual observed in this study was an isolated case of visible contamination by oil, indicating that the number of sea turtles on the Paraíba coast affected by contact with oil spills would appear to be low.

Collision with vessels is further evidence of human interaction being related to strandings, and is often the cause of sea turtle death. Casale et al. (2010) point out that collision with vessels was the second most common cause of sea turtle death in the Mediterranean. However, in the present study this interaction was not very common: the strandings indicated that collisions occurred with the carcass, not with a living turtle. Regarding evidence of intentional injuries caused by sharp or spiked objects, two main reasons are sustained to justify these activities: the use of turtle meat for food and of the carapace keratin plates for manufacture of ornamental items, or fishing artifact protection when animals, particularly large ones, are caught and, in their struggle, rip the nets. This is corroborated by logistic regression, which showed that larger individuals are more susceptible to these types of injuries. The use of the meat for consumption, and the carapace for the preparation and sale of ornamental items has been reported in some Brazilian cities (Marcovaldi and Dei Marcovaldi, 1999).

The occurrence of tumors in green turtles was expected, since FP disease is recognized as more frequently affecting this species (Aguirre and Lutz, 2004; Foley et al., 2005; Reis et al., 2010b). Mascarenhas and Iverson (2008) report tumors suggestive of FP in $26 \%$ of the strandings observed on the Paraíba coast. Compared to that study, the results of the present study showed a small increase in the incidence of these tumors, and, moreover, we observed the presence of both external and internal tumors in three animals, especially in the lungs and intestine. The higher incidence of tumors in individuals with CCLs of between 30 and $80 \mathrm{~cm}$ corroborates previous studies that report juveniles as those that are mostly affected by FP (Aguirre and Lutz, 2004; Chaloupka et al., 2008). Foley et al. (2005) suggest that the lack of FP in the smaller size classes (up to $30 \mathrm{~cm}$ ) could be explained by a lack of sufficient time for disease symptoms to appear and, later, when these individuals begin to migrate to coastal areas, they are exposed to a greater concentration of pollutants (a possible co-factor associated with FP), which could contribute to triggering the disease. The sharp fall in the prevalence of the disease in animals with CCLs $<80 \mathrm{~cm}$ could be explained by a regression of tumors with age, or as a result of mortality of individuals with FP before they have reached a larger size (Foley et al., 2005). In addition, Van Houtan et al. (2010) in their study reveal the relationship between turtle size, eutrophication of foraging areas and the incidence of invasive algae with the emergence of FP in green turtles. By correlating disease with environmental factors, the occurrence of FP can be used to evaluate ecosystem health (Reis et al., 2010b).

The significant seasonality observed in the occurrence of strandings is probably related to the increase of anthropogenic activities combined with the turtles migrating to their nesting grounds. Fishing activities are more intense along the Paraíba coast during the spring and summer (IBAMA, 2008). Moreover, during this period the movement of tourist boats and the accumulation of marine debris on beaches are both greater in this area (Mascarenhas et al., 2008).

We conclude that, despite conservation efforts and the current Brazilian laws that penalize harmful practices that threaten species, a range of human activities still endanger sea turtle survival in the long-term. Fishing remains a serious problem on the Paraíba coast, and interaction with anthropogenic debris, as well as the significant incidence of FP, reveals a worrying environmental degradation. Urgent measures are necessary, such as an increase in environmental education activities and programs of regeneration and environmental protection. Although there are numerous studies on strandings of all sea turtle species, continued monitoring is necessary along the entire Brazilian coast. Furthermore, studies of population size, including tagging, genetic analyses and behavioural studies, will be extremely important in estimating the impact of mortality in this specific population.

Acknowledgements - We would like to thank the entire team of volunteers of Projeto Tartarugas Urbanas (Associação Guajiru) for their help in field work, the Coordenação de Aperfeiçoamento de Pessoal de Nível Superior (CAPES) for their financial support, $\mathrm{CNPq}$ for a research fellowship for DOM, and the Programa de Pós-graduação em Ciências Biológicas da Universidade Federal da Paraíba for supporting this study.

\section{References}

AGUIRRE, A. and LUTZ, P., 2004. Marine turtles as sentinels of ecosystem health: is fibropapillomatosis an indicator? EcoHealth, vol. 1 , no. 3 , p. 275-283. 
AYRES, M., AYRES JUNIOR, M., AYRES, DL. and SANTOS, AAS., 2007. BioEstat 5.0: aplicações estatísticas nas áreas das ciências biológicas e médicas. Belém: Sociedade Civil Mamirauá.

BALAZS, G., 1985. Impact of ocean debris on marine turtles: entanglement and ingestion. In Proceedings of the Workshop on the Fate and Impact of Marine Debris, 1984. Honolulu, Hawaii: US Departament of Commerce. p. 387-429.

BAPTISTOTTE, C., THOMÉ, JCA. and BJORNDAL, KA., 2003. Reproductive biology and conservation status of the loggerhead sea turtle (Caretta caretta) in Espírito Santo State, Brazil. Chelonian Conservation and Biology, vol. 4, no. 3, p. 1-7.

BJORNDAL, KA., 1999. Priorities for research in foraging habitats. In ECKERT, KL., BJORNDAL, KA., ABREU-GROBOIS, FA. and DONELLY, M. (Ed.). Research and management techniques for the conservation of sea turtles. Washington: IUCN/SSC MarineTurtle Specialist Group. p. 12-14. IUCN/SSC Marine Turtle Specialist Group Publication, vol. 4.

BJORNDAL, KA., BOLTEN, AB. and LAGUEUX, CJ., 1994. Ingestion of marine debris by juvenile sea turtles in coastal Florida habitats. Marine Pollution Bulletin, vol. 28, no. 3, p. 154-158. http://dx.doi.org/10.1016/0025-326X(94)90391-3.

BOLTEN, AB., 2003. Variation in sea turtle life history patterns: neritic vs. oceanic developmental stages. In LUTZ, PL., MUSICK, JA. and WYNEKEN, J. (Ed.). The biology of sea turtles. Boca Raton: CRC Press. vol. 2. p. 243-258.

BUGONI, L., KRAUSE, L. and VIRGÍNIA PETRY, MV., 2001. Marine debris and human impacts on sea turtles in southern Brazil. Marine Pollution Bulletin, vol. 42, no. 12, p. 1330-1334. http:// dx.doi.org/10.1016/S0025-326X(01)00147-3. PMid:11827120

BUGONI, L., NEVES, TS., LEITE JUNIOR, NO., CARVALHO, D., SALES, G., FURNESS, RW., STEIN, CE., PEPPES, FV., GIFFONI, BB. and MONTEIRO, DS., 2008. Potential bycatch of seabirds and turtles in hook-and-line fisheries of the Itaipava Fleet, Brazil. Fisheries Research, vol. 90, no. 1-3, p. 217-224. http://dx.doi.org/10.1016/j.fishres.2007.10.013.

CAMPBELL, LM., 2003. Contemporary culture, use, and conservation of sea turtles. In LUTZ, PL., MUSICK, JA. and WYNEKEN, J. (Ed.). The biology of sea turtles. Boca Raton: CRC Press. vol. 2. p. 307-338.

CASALE, P., AFFRONTE, M., INSACCO, G., FREGGI, D., VALLINI, C., PINO D'ASTORE, P., BASSO, R., PAOLILLO, G., ABBATE, G. and ARGANO, R., 2010. Sea turtle strandings reveal high anthropogenic mortality in Italian waters. Aquatic Conservation: Marine and Freshwater Ecosystems, vol. 20, no. 6, p. 611-620. http://dx.doi.org/10.1002/aqc.1133.

CASTILHOS, JC., COELHO, CA., ARGOLO, JF., SANTOS, EAP., MARCOVALDI, MA., SANTOS, AS. and LOPEZ, M., 2011. Avaliação do estado de conservação da tartaruga marinha Lepidochelys olivacea (Eschscholtz, 1829) no Brasil. Biodiversidade Brasileira, vol. 1, n. 1, p. 28-36.

CHALOUPKA, M., WORK, T., BALAZS, G., MURAKAWA, S. and MORRIS, R., 2008. Cause-specific temporal and spatial trends in green sea turtle strandings in the Hawaiian Archipelago (1982-2003). Marine Biology, vol. 154, no. 5, p. 887-898. http:// dx.doi.org/10.1007/s00227-008-0981-4.

EPPERLY, SP., BRAUN, J., CHESTER, AJ., CROSS, FA., MERRINER, JV., TESTER, PA. and CHURCHILL, JH., 1996. Beach strandings as an indicator of at-sea mortality of sea turtles. Bulletin of Marine Science, vol. 59, no. 2, p. 289-297.
FOLEY, AM., SCHROEDER, BA., REDLOW, AE., FICK-CHILD, KJ. and TEAS, WG., 2005. Fibropapillomatosis in stranded green turtles (Chelonia mydas) from the eastern United States (1980-98): trends and associations with environmental factors. Journal of Wildlife Diseases, vol. 41, no. 1, p. 29-41. http://dx.doi. org/10.7589/0090-3558-41.1.29. PMid:15827208

FOX, J., 2005. The R Commander: A Basic-Statistics Graphical User Interface to R. Journal of Statistical Software, vol. 14, no. 9, p. 1-42.

GEORGE, RH., 1997. Health problems \& diseases of sea turtles. In LUTZ, PL., MUSICK, JA. and WYNEKEN, J. (Ed.). The biology of sea turtles. Boca Raton: CRC Press. vol. 1. p. 363-387.

GROSSMAN, A., MENDONÇA, P., COSTA, MR. and BELLINI, C., 2007. Morphometrics of the green turtle at the Atol das Rocas Marine Biological Reserve, Brazil. Marine Turtle Newsletter, vol. 118 , p. 12-13

GUEBERT-BARTHOLO, F., BARLETTA, M., COSTA, M. and MONTEIRO-FILHO, E., 2011. Using gut contents to assess foraging patterns of juvenile green turtles Chelonia mydas in the Paranaguá; Estuary, Brazil. Endangered Species Research, vol. 13, no. 2, p. 131-143. http://dx.doi.org/10.3354/esr00320.

HERBST, LH., 1994. Fibropapillomatosis of marine turtles. Annual Review of Fish Diseases, vol. 4, p. 389-425. http://dx.doi. org/10.1016/0959-8030(94)90037-X.

Instituto Brasileiro do Meio Ambiente e dos Recursos Naturais Renováveis - IBAMA, 2008. Monitoramento da atividade pesqueira no litoral nordestino: Projeto Estatpesca. Tamandaré.

International Union for Conservation of Nature and Natural Resources - IUCN, 2011. The IUCN Red List of Threatened Species. Available from: $<\mathrm{http}: / / \mathrm{www}$.iucnredlist.org $>$. Access in: 23 Apr. 2014.

IVAR DO SUL, JA. and COSTA, MF., 2007. Marine debris review for Latin America and the wider Caribbean region: from the 1970s until now, and where do we go from here? Marine Pollution Bulletin, vol. 54, no. 8, p. 1087-1104. http://dx.doi. org/10.1016/j.marpolbul.2007.05.004. PMid:17624374

LIMA, EHSM., MELO, DMT. and BARATA, PCR., 2010. Incidental capture of sea turtles by the lobster fishery of the Ceará Coast, Brazil. Marine Turtle Newsletter, vol. 128, p. 16-19.

LUTCAVAGE, ME., PLOTKIN, P., WITHERINGTON, BE. and LUTZ, PL., 1997. Human impacts on sea turtle survival. In LUTZ, PL., MUSICK, JA. and WYNEKEN, J. (Ed.). The biology of sea turtles. Boca Raton: CRC Press. vol. 1. p. 387-409.

MARCOVALDI, MA. and CHALOUPKA, M., 2007. Conservation status of the loggerhead sea turtle in Brazil: an encouraging outlook. Endangered Species Research, vol. 3, no. 2, p. 133-143. http://dx.doi.org/10.3354/esr003133.

MARCOVALDI, MA., LOPEZ, GG., SOARES, LS., BELINI, C., SANTOS, AS. and LOPEZ, M., 2011. Avaliação do estado de conservação da tartaruga marinha Eretmochelys imbricata (Linnaeus, 1766) no Brasil. Biodiversidade Brasileira, vol. 1, n. 1 , p. $20-27$.

MARCOVALDI, MÂ. and DEI MARCOVALDI, GG., 1999. Marine turtles of Brazil: the history and structure of Projeto TAMAR-IBAMA. Biological Conservation, vol. 91, no. 1, p. 35-41. http://dx.doi.org/10.1016/S0006-3207(99)00043-9.

MARCOVALDI, MA., SALES, G., THOMÉ, JCA., SILVA, ACCD., GALLO, BM., LIMA, EHSM., LIMA, EP. and BELLINI, 
C., 2006. Sea turtles and fishery interactions in Brazil: identifying and mitigating potential conflicts. Marine Turtle Newsletter, vol. 112 , p. 4-8.

MARTINS, M. and MOLINA, FB., 2008. Répteis: panorama geral dos répteis ameaçados do Brasil. In: MACHADO, ABM., DRUMMOND, GM. and PAGLIA, AP. (Ed.). Livro vermelho da fauna brasileira ameaçada de extinção. Brasília: Ministério do Meio Ambiente. vol. 2. p. 897.

MASCARENHAS, R., BATISTA, CP., MOURA, IF., CALDAS, AR., COSTA-NETO, JM., VASCONCELOS, MQ., ROSA, SS. and BARROS, TVS., 2008. Lixo marinho em área de reprodução de tartarugas marinhas no Estado da Paraíba (Nordeste do Brasil). Revista de Gestão Costeira Integrada, vol. 8, no. 2, p. 221-231.

MASCARENHAS, R. and IVERSON, PJ., 2008. Fibropapillomatosis in stranded green turtles (Chelonia mydas) in Paraiba State, Northeastern Brazil: evidence of a Brazilian epizootic? Marine Turtle Newsletter, vol. 120, p. 3-6.

MASCARENHAS, R., SANTOS, R. and ZEPPELINI, D., 2004. Plastic debris ingestion by sea turtle in Paraíba, Brazil. Marine Pollution Bulletin, vol. 49, no. 4, p. 354-355. http://dx.doi. org/10.1016/j.marpolbul.2004.05.006. PMid: 15341830

MASCARENHAS, R., SANTOS, R. and ZEPPELINI, D., 2005. Stranded sea turtles on the coast of Paraíba, Brazil. Marine Turtle Newsletter, vol. 107, p. 13-14.

MASCARENHAS, R., ZEPPELINI, D. and MOREIRA, VS., 2003. Observations on sea turtles in the State of Paraíba, Brazil. Marine Turtle Newsletter, vol. 101, p. 16-18.

MCCAULEY, SJ. and BJORNDAL, KA., 1999. Conservation implications of dietary dilution from debris ingestion: sublethal effects in post-hatchling loggerhead sea turtles. Conservation Biology, vol. 13, no. 4, p. 925-929. http://dx.doi.org/10.1046/j.15231739.1999.98264.x.

MROSOVSKY, N., RYAN, GD. and JAMES, MC., 2009. Leatherback turtles: the menace of plastic. Marine Pollution Bulletin, vol. 58, no. 2, p. 287-289. http://dx.doi.org/10.1016/j. marpolbul.2008.10.018. PMid:19135688

OLIVEIRA, PA., VENDEL, AL. and CRISPIM, MCB., 2009. Caracterização socioeconômica e registro da percepção dos pescadores de lagosta das praias do Seixas e Penha, João Pessoa, PB. Boletim do Instituto de Pesca, vol. 35, no. 4, p. 637-646.

PLOTKIN, P. and AMOS, AF., 1990. Effects of anthropogenic debris on sea turtles in the northwestern Gulf of Mexico. In Proceedings of the Second International Conference on Marine Debris, 1990. Honolulu, Hawaii: US Departament of Commerce. p. 736-743.

REIS, EC., MOURA, JF., LIMA, LM., RENNÓ, B. and SICILIANO, S., 2010a. Evidence of migratory movements of olive ridley turtles (Lepidochelys olivacea) along the Brazilian coast. Brazilian
Journal of Oceanography, vol. 58, no. 3, p. 255-259. http:// dx.doi.org/10.1590/S1679-87592010000300009.

REIS, EC., PEREIRA, CS., RODRIGUES, DDP., SECCO, HKC., LIMA, LM., RENNÓ, B. and SICILIANO, S., 2010b. Condição de saúde das tartarugas marinhas do litoral Centro-Norte do Estado do Rio de Janeiro, Brasil: avaliação sobre a presença de agentes bacterianos, fibropapilomatose e interação com resíduos antropogênicos. Oecologia Australis, vol. 14, no. 3, p. 756-765. http://dx.doi.org/10.4257/oeco.2010.1403.11.

REIS, EC., SILVEIRA, VVB. and SICILIANO, S., 2009. Records of stranded sea turtles on the coast of Rio de Janeiro State, Brazil. Marine Biodiversity Records. vol. 2, e121.

RYAN, PG., MOORE, CJ., VAN FRANEKER, JA. and MOLONEY, CL., 2009. Monitoring the abundance of plastic debris in the marine environment. Philosophical transactions of the Royal Society of London. Series B, Biological sciences, vol. 364, no. 1526, p. 1999-2012. http://dx.doi.org/10.1098/rstb.2008.0207. PMid:19528052

SANTOS, AJB., FREIRE, EMX., BELLINI, C. and CORSO, G., 2010. Body mass and the energy budget of gravid hawksbill turtles (Eretmochelys imbricata) during the nesting season. Journal of Herpetology, vol. 44, no. 3, p. 352-359. http://dx.doi. org/10.1670/08-287.1.

SANTOS, AS., SOARES, LS., MARCOVALDI, MA., MONTEIRO, DS., GIFFONI, B. and ALMEIDA, AP., 2011. Avaliação do estado de conservação da tartaruga marinha Caretta caretta Linnaeus, 1758 no Brasil. Biodiversidade Brasileira, vol. 1, no. 1, p. 3-11.

SILVA, ACCD., CASTILHOS, JC., LOPEZ, GG. and BARATA, PCR., 2007. Nesting biology and conservation of the olive ridley sea turtle (Lepidocheyls olivacea) in Brazil, 1991/1992 to 2002/2003. Journal of the Marine Biological Association of the United Kingdom, vol. 87, no. 4, p. 1047-1056.

TOURINHO, PS., IVAR DO SUL, JA. and FILLMANN, G., 2010. Is marine debris ingestion still a problem for the coastal marine biota of southern Brazil? Marine Pollution Bulletin, vol. 60, no. 3, p. 396-401. http://dx.doi.org/10.1016/j.marpolbul.2009.10.013. PMid:19931101

VAN HOUTAN, KS., HARGROVE, SK. and BALAZS, GH., 2010. Land use, macroalgae, and a tumor-forming disease in marine turtles. PLoS ONE, vol. 5, no. 9, p. e12900. http://dx.doi. org/10.1371/journal.pone.0012900. PMid:20927370

WHITING, SD., LONG, JL. and COYNE, M., 2007. Migration routes and foraging behaviour of olive ridley turtles Lepidochelys olivacea in northern Australia. Endangered Species Research, vol. 3, no. 1, p. 1-9. http://dx.doi.org/10.3354/esr003001.

ZAR, JH., 1999. Biostatistical analysis. New Jersey: Prentice-Hall. 